\title{
The hydraulic safeguard of the city of Milan: the Canale Scolmatore di Nord-Ovest
}

\author{
G. La Montagna \\ Agenzia Interregionale per il fiume Po (A.I.Po), Milano, Italy
}

\begin{abstract}
The hydraulic safety of the city of Milan has always been a primary objective in the management of the territory of Regione Lombardia. The alluvial phenomena that, more and more frequently, have interested the territories of the metropolitan area and immediately upstream, towards the north-west (director MilanoGallarate-Varese) and towards the north (Brianza), have brought over time huge economic losses and determined in the local populations a perennial sense of anguish. The complexity of the so-called "Milanese hydraulic node", connected to the ferocious anthropization that has characterized these territories for centuries, and especially during the years of the "economic boom" (fifties and sixties), has always constituted an enormous obstacle for the administrations, both for problems in management and in economic terms. At the end of the past century the increasing emergency requirements have only begun to find concrete answers from the institutions, initially by means of the Piano di Assetto Idrogeologico (ex L. 183/89) and then by means of the Laws issued by Regione Lombardia (since 1998 competent in matter of territorial defence). Today, the hydraulic order of the safety system of the city of Milan is under adaptation and the realization of the planned and programmed participations will guarantee facing the hydraulic emergency during events with great return periods. In this paper the peculiarities of this hydraulic system and the institutional instruments and the solutions apt to guarantee the functionality of the system in front of the changed territorial scenes have been described.
\end{abstract}




\section{The catchment of the city of Milano}

The Milanese catchment is characterized by numerous water courses, in a very large area delimited north from the PreAlps, south from the Po river, west from the Ticino river and east from the Adda river.

The entire hydrographical network can be led back to the Lambro Settentrionale river, affluent of the Po river that collects the contributions of the entire subcatchment called Lambro-Seveso-Olona [fig. 1].

The natural water courses are:

$\begin{array}{ll}\text { - } & \text { Olona river which discharges entirely in the colatore Lambro } \\ \text { - } & \text { Bozzente and Lura torrents, affluent of the Olona; } \\ \text { - } & \text { Groane torrent; } \\ \text { - } & \text { Seveso torrent, which discharges entirely in Naviglio Martesana; } \\ \text { - } & \text { Molgora torrent, which discharges in the Muzza Canal; } \\ \text { - } & \text { Trobbia torrent; }\end{array}$

The artificial stream channels are:

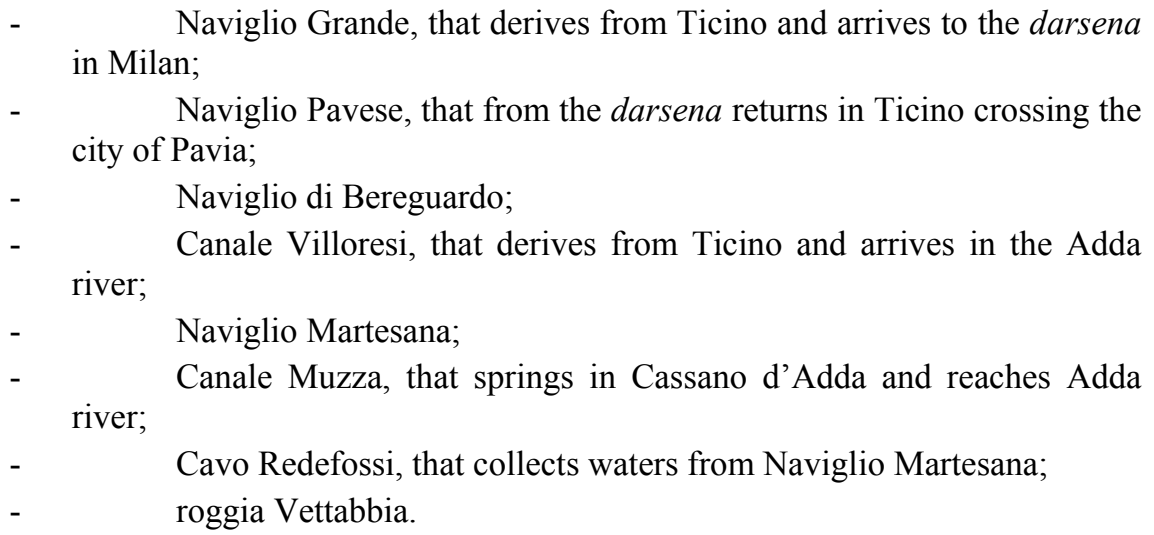

The city of Milan lies in the centre of this drainage network. Centuries ago rivers originally ran far away from the city, but later on, water derivation works done to use hydraulic power, brought them nearer to the city area.

For this reason, nowadays Milan is a complex hydraulic node and its urban territory is crossed by all major rivers, except for the Northern Lambro river.

The natural streams system is also linked to the artificial channels system of the Navigli, historical navigable water-ways used by the city.

A strong anthropic area footprint acted on the hinterland, along two directions, the Milano-Busto-Varese and the Milano-Seveso-Erba, thus causing a great change in the hydraulic regime of the greater order streams.

The cross sectional area of the Olona river, as well as the Seveso's, is unlikely to contain the discharge associated with a return period of 10 years. 
The uncontrolled increase of impervious surfaces together with poor designing of sewage system and drainage networks lead to an increase in runoff volumes and to a reduction of concentration times, favouring superimposition of flood waves.

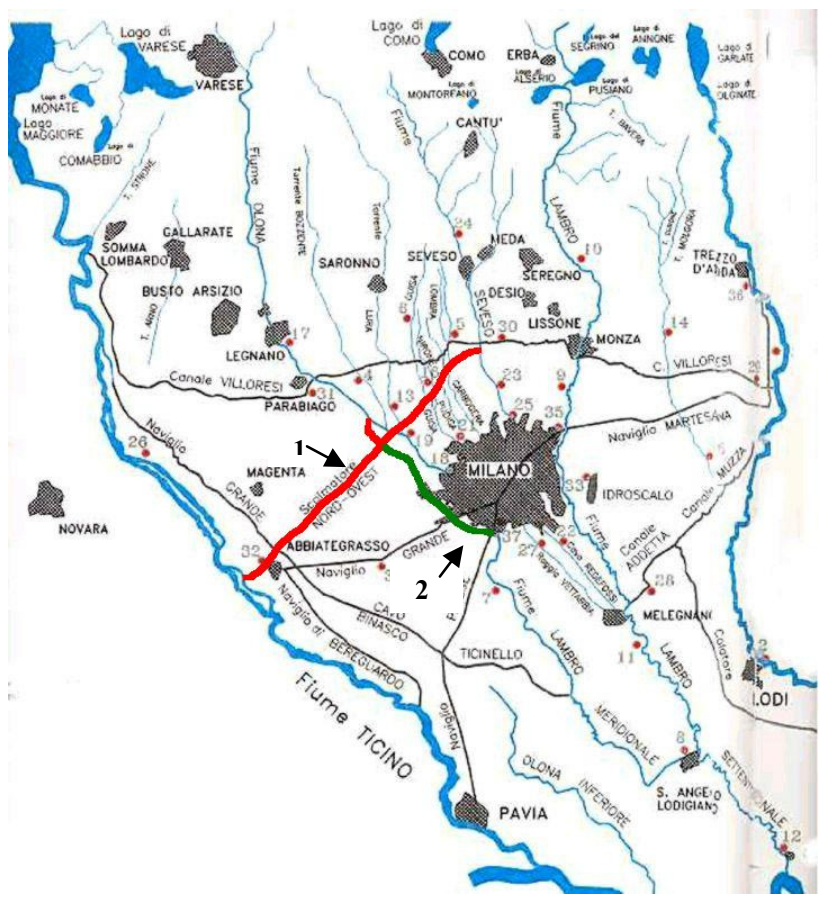

Figure 1: The Milanese hydrographical reticulum; bold-line number 1 the CSNO, bold-line number 2 Deviatore Olona; the intersection is the node of Vighignolo.

\section{The hydraulic defence of the city of Milano}

During the Seventies a series of risk mitigation works started in the city of Milan. The aim of these works was reducing the exceeding discharges flowing through the urban areas because the drainage network was unable to convey them. In fact, by the first half of the twentieth century the complex Navigli waterway had been either covered or filled up, and as previously stated, the Olona, Lambro Meridionale and Seveso rivers belonged to the Navigli waterway system.

The main works were:

- Canale Scolmatore di Nord-Ovest (CSNO), which collects, north of Milan, the higher discharges of Seveso river and the Groane and Olona torrents; 
- Deviatore Olona, which collects upstreams waters of the CSNO, in order to avoid to send them in Ticino;

- Deviatore Redefossi, which collects part of the water discharge of Cavo Redefossi.

The main problem of Milan hydraulic system is due to the inadequacy of the cross sections of Seveso and CSNO. Moreover, today the Olona/Lambro Meridionale river and the Cavo Redefossi run underneath the metropolitan area of Milan, again with insufficient cross section areas.

The case of the Seveso is particularly meaningful.

Despite the construction of the "presa Seveso" of CSNO, which is able to divert up to $30 \mathrm{~m}^{3} / \mathrm{s}$, some areas of Milan (e.g. Niguarda) are still flooded.

In 1988 a study commissioned by the Municipality of Milano brought to evidence the necessity to upgrade the draining efficiency of Seveso in CSNO. Such necessity was, in 1999, the base on which the Agreement Program for the safeguard of the City of Milan was stipulated.

\section{Current defence of Milano and the role of the Deviatore Olona}

In today's hydraulic framework of the sub-drainage Lambro-Seveso-Olona (LSO) rivers, only Ticino and Adda rivers can accommodate discharge of streams when this becomes too high, without altering normal stream channel and regime.

Therefore the CSNO is of fundamental importance due to its action of transferring any excess discharge of the LSO to the Ticino river (fig. 2).

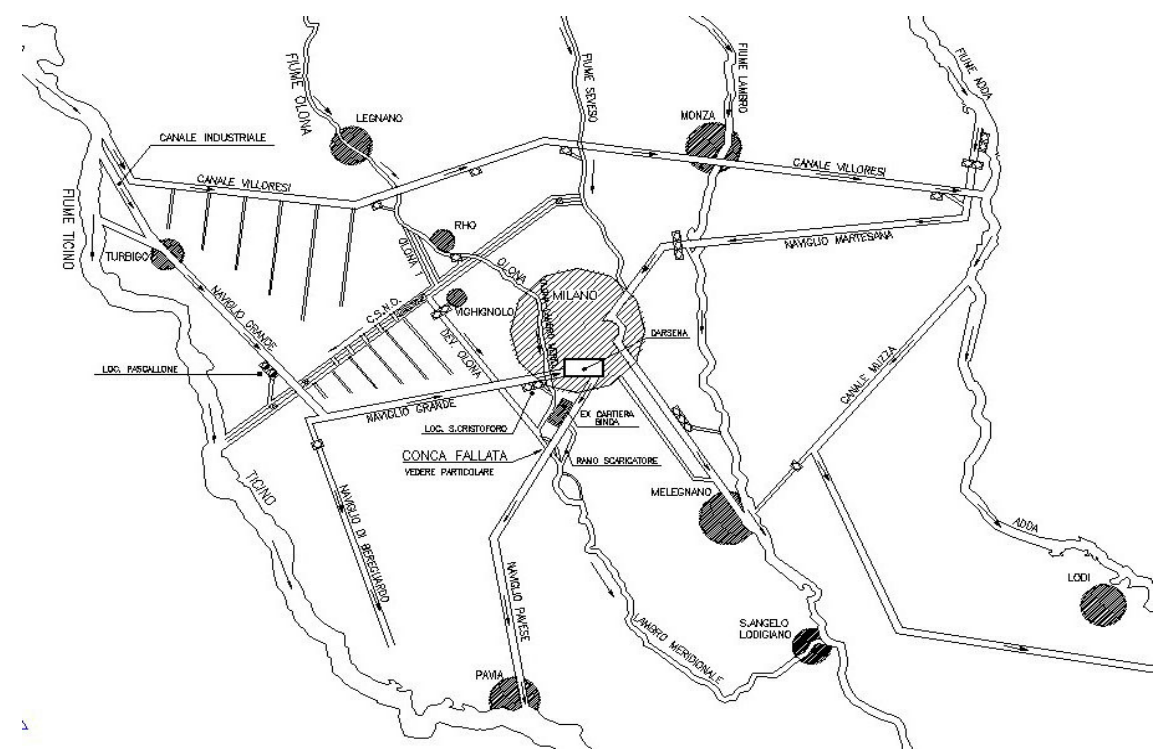

Figure 2: The outline of the water reticulum in its current order. 
The Canale Scolmatore shows typical artificial stream channel patterns, with ramp-and-flats, underground flow, siphons, etc, breaking the long stretches with constant slope and constant cross sectional shape.

The CSNO is divided in three branches, two of which converging towards the Vighignolo node, while the third one goes from the node towards Ticino river. The Vighignolo node is also the starting point of the Deviatore Olona, the other risk mitigation work.

\subsection{First segment: "Seveso branch"}

Moving downhill, the first branch of the Canale Scolmatore di Nord Ovest (CSNO) that we encounter is known as the "Seveso branch". This is $14 \mathrm{~km}$ long and its starting point called "presa Seveso" is situated in the town of Paderno Dugnano at Palazzolo.

Besides draining the Seveso river, this branch also collects the overflows of the Groane torrent, when the discharge becomes too high.

The same happens for Lura and Olona rivers which have a spillway: when the discharge exceeds a threshold, water flows into the Seveso branch.

Furthermore, in the Municipality of Rho, there is a subsidiary draining site, known as "Olona 2", with a discharge potential of $15 \mathrm{~m}^{3} / \mathrm{s}$.

\section{The "Seveso barrage"}

This is a structure of great importance because most of Milan hydraulic safeguard relies on it.

It consists of floodgates working as a spillway control system, diverting Seveso waters into the CSNO when the water level of $1.86 \mathrm{~m}$ is overcome.

In order to allow water to pass without lifting the sluice gates, there is a flat spillway sill placed at a height of $0.6 \mathrm{~m}$.

The Seveso barrage has undergone some upgrade during the works needed to double the CSNO discharge potential up to $60 \mathrm{~m}^{3} / \mathrm{s}$.

Today though, the CSNO, due to the not yet completed works mentioned above, can drain maximum $30 \mathrm{~m}^{3} / \mathrm{s}$.

\subsection{Second segment: "Olona branch"}

It is $5 \mathrm{~km}$ long and it branches off the Olona river, north of the town of Rho.

This overflow is known as "Olona 1 " and has a draining potential of $25 \mathrm{~m}^{3} / \mathrm{s}$.

\subsection{The Vighignolo node at Settimo Milanese}

At present, summing up all the contributions from Seveso river, Groane torrents, "Olona 2" and Lura, the discharge conveyed to the Vighignolo hydraulic junction is equal to $70 \mathrm{~m}^{3} / \mathrm{s}$.

This is the most important junction in the flood prevention and protection system of the city of Milan. 
In this node a number of gates are positioned and used to control water levels and to divert incoming flows from urban areas; these gates are operated by the Province of Milan.

The node is also the starting point for Deviatore Olona and for the third branch of CSNO.

Low discharges (smaller than $30 \mathrm{~m}^{3} / \mathrm{s}$ ) are not diverted in the Deviatore Olona, to avoid flowing of heavily polluted waters into the Ticino river. Water is discharged in the Souther Lambro, south of Milan, upstream of the Naviglio Pavese siphon, near Conca Fallata.

\subsection{The Deviatore Olona and the design of adaptation of the outflow sections}

Because of the damages caused by the various floods occurred in the first half of the XX century, in April 1951 a decree of the President of the Lombardy Region classified as Third Category the hydraulic works necessary to start land reclamation in the province in Milan. The related projects were approved in 1954 by the Ministry of Public Works.

Works to alter the course of the Souther Lambro river, between Naviglio Grande and Naviglio Pavese, date back to 1952. In order to rearrange the hydraulic network system of the Conca Fallata node, Southern Lambro was made to discharge into the Lambretto, crossing the Naviglio Pavese, flowing through a new and wider siphon. This way the former segment of Lambro worked as an additional spillway. A weir was positioned in the junction in order to control Lambro river higher discharge. The above mentioned segment runs across the area of a former manufacturing industry, which has been nowadays refurbished and turned in residential settlements, and underneath the ancient Naviglio Pavese canal bridge.

During the second half of the 60s, the Deviatore Olona was designed in order to decrease the water discharges flowing in the metropolitan segment of the Olona river.

Works to improve the profile and the cross sections of the Southern Lambro river ended in 1961; the works on Deviatore Olona finished after 1980, and now it collects CSNO higher discharges before flowing into the Ticino river.

Following the signature, in 1999, of the Accordo di Programma for the hydraulic safeguard of Milan, a new proposal was made: to divert the CSNO discharge, estimated around $30 \mathrm{~m}^{3} / \mathrm{s}$, into the Deviatore Olona and then into the Souther Lambro river.

Within a short time works to bring the Deviatore draining potential up to $40 \mathrm{~m}^{3} / \mathrm{s}$ are going to be handed over to contractors.

\subsection{Third segment: from the Vighignolo junction to the Ticino river}

This is the longest segment: it is almost $20 \mathrm{~km}$ and the last $5 \mathrm{~km}$ are suspended on the surrounding flood plain. It transfers the flow outcoming from Vighignolo to the Abbiategrasso territory, and drains the excess discharge flowing from Deviatore Olona. 


\section{The Accordo di Programma (AdP) for the safeguard of the metropolitan area of Milan}

In 1999 the need for planning and checking all the scheduled works to adapt the functionality of the hydraulic safeguard system of Milan, lead all the Public Bodies involved to sign the Agreement for the Safeguard of Milan (AdP).

The Agreement was approved with Decree of the Lombardy Region President on the $5^{\text {th }}$ August 1999.

After the signature, the State government was no longer responsible for soil protection, being this responsibility handed over to the Regions, like Lombardy Region, to the Po Basin Authority, the Magistrato for the Po river, the Milano Province and Municipality.

\subsection{The A.d.P. "for the hydraulic safeguard of the City of Milano" in 1999}

The target of the Agreement was to point out and examine all proposals concerning projects aimed to improve the hydraulic safeguard of the city and their economic aspects.

For the Vighignolo node and the Seveso river, the A.d.P requires "to define the capacities of the hydraulic sections" and "the hypotheses of order for the works of hydraulic safeguard of Milan on short and medium terms: the doubling of the CSNO, the dimensioning of the CSNE, the use of Deviatore Olona".

Moreover, it defined the realization of the extraordinary repairs and lamination works on the Olona, Bozzente, Lura and Guisa rivers, defining also the most urgency interventions.

Among the works of maximum priority there is the "adaptation of the CSNO in order to increase the discharges derived from Seveso from 30 to the $60 \mathrm{~m}^{3} / \mathrm{s}$ ".

In the same document the resources for financing of the works and the relative articulation between the agencies were defined.

Afterwards, a contract was stipulated between Magistrato per il Po, Regione Lombardia, Province of Milano and Milano Municipality for "the realisation, the improvement, the maintenance and the management of the hydraulic works to defence of Milan and of its hinterland".

\subsection{L'A.d.P. "for the hydraulic safeguard and the requalification of the water courses of the hinterland" in 2009}

The first A.d.P. lasted ten years and expired in March of 2009; unfortunately, not all the planned interventions were realized.

Moreover, changes from the initial plans were required, due to the development of the sewerage systems.

Furthermore, in 2008 the city of Milan was appointed for organizing the Universal Exposure of the 2015 (Expo 2015), paying attention at the topic of the water and to its use within the urban and environmental system connected with the so-called water ways. 
The changed programmatic and managerial requirements drove towards the definition of a new A.d.P. with new challenging targets.

\section{The interventions of functional adaptation of the CSNO}

A first functional feature of the adaptation works was realized in the 2004/05 from the Province of Milan funded by the Magistrato per il Po/AIPo.

Following the Feasibility study drawn up in 2007 by the Province of Milano, it became evident the need to increase the discharge capacity of the Seveso branch of the Canale Scolmatore. This was necessary to decrease the amount of water flowing into the metropolitan segment of the Seveso river.

Today, in case of high discharge conditions of the Seveso river, $30 \mathrm{~m}^{3} / \mathrm{s}$ can be diverted into the CSNO.

Among the various actions to be undertaken, it worth mentioning the upgrading works on the Canale itself and the facilities interfering with it, to be able to divert a greater amount of water Seveso.

The new discharge value has been assessed through a cost-benefit analysis of the project.

In the 2009 AIPo, in collaboration with the Province of Milan, planned the adaptation works.

Based on a topographic survey and a hydrogeological study, run by AIPo in 2004, a steady flow analysis was carried out to determine the critical features in the flow distribution pattern of the Canale under different discharge conditions.

The first works to start with were outlined on the basis of new data gathered from further and more detailed geological, topographic and hydrological surveys.

The works had to guarantee the flow of the assessed maximum discharge value and therefore a new hydraulic analysis was run using planned discharge values.

A temporary discharge value was also defined, as in the final configuration the CSNO will be provided with detention tanks (not currently working), positioned in the town of Senago; these tanks, according to AIPO and Province of Milan plans, will allow to divert from Seveso a discharge up to $60 \mathrm{~m}^{3} / \mathrm{s}$, while the maximum discharge outflowing from the tank into the Canale will be equal to only $25 \mathrm{~m}^{3} / \mathrm{s}$.

In the so determined "temporary" conditions the maximum discharge that can be diverted from Seveso river is equal to $36 \mathrm{~m}^{3} / \mathrm{s}$, that is, $20 \%$ more than the present allowable discharge.

\subsection{Hydraulic outline of the project}

In order to plan the interventions of adaptation of CSNO, using the collected hydrological data, the hydraulic analysis was concentrated on the behaviour of the channel in conditions of current and design state, according to the two discharges defined in the study of feasibility of the Province of Milan.

The smaller discharges have still a return period equal to 100 years. In table 1 the discharges used for hydraulic dimensioning the Scolmatore are shown. 
Table 1: $\quad$ Discharges for hydraulic dimensioning of CSNO.

\begin{tabular}{|c|c|c|c|}
\hline Branch & $\begin{array}{c}\text { Length } \\
{[\mathbf{k m}]}\end{array}$ & $\begin{array}{c}\text { Temporary } \\
\mathbf{d i s c h a r g e} \\
{\left[\mathbf{m}^{\mathbf{3}} / \mathbf{s}\right]}\end{array}$ & $\begin{array}{c}\text { Planned } \\
\mathbf{d i s c h a r g e} \\
{\left[\mathbf{m}^{\mathbf{3}} / \mathbf{s}\right]}\end{array}$ \\
\hline from presa Seveso to via Brodolini bridge & 2,9 & 36 & 60 \\
\hline $\begin{array}{c}\text { from via Brodolini bridge to T. Garbogera } \\
\text { confluence }\end{array}$ & 0,2 & 36 & 25 \\
\hline $\begin{array}{c}\text { from T. Garbogera confluence to T. Pudiga } \\
\text { confluence }\end{array}$ & 0,9 & 42 & 31 \\
\hline $\begin{array}{c}\text { from T. Pudiga confluence to T. Nirone } \\
\text { confluence }\end{array}$ & 0,8 & 55 & 43 \\
\hline $\begin{array}{c}\text { from T. Nirone confluence to T. Guisa } \\
\text { confluence }\end{array}$ & 1,2 & 56 & 43 \\
\hline $\begin{array}{c}\text { from T. Guisa confluence to shunter T. Lura } \\
\text { confluence }\end{array}$ & 3,3 & 64 & 50 \\
\hline $\begin{array}{c}\text { from shunter T. Lura confluence to F. Olona } \\
\text { confluence }\end{array}$ & 1,2 & 77 & 63 \\
\hline from F. Olona confluence to Vighignolo node & 2,4 & 90 & 75 \\
\hline
\end{tabular}

The greater values of discharge refer to the "transitory" plan without storage areas and are used for the verification of compatibility of the works of crossing and the river bed section of the channel. The long-term plan, instead, considers the presence of the storage areas in correspondence of the feature of channel to valley of the breaking in of Garbogera river.

\section{Conclusions}

The Lambro-Seveso-Olona catchment is the area in Lombardy with the largest ecological footprint consisting of both strong urban pressure, given by over 5 million inhabitants, which is more than $50 \%$ of Lombardy's population, and strong industrial pressure.

In the past years Lombardy Region has promoted a series of actions and tools, as the "River Contracts", with the purpose to give an integrated overview of the river system in terms of urban and environmental restoration.

With this in mind, in 2009 a new Agreement Program was signed.

Works concerning the upgrade of the CSNO play a prior role in above Agreement.

A number of "structural" and "non-structural" actions have been planned. The most important of the latter is the implementation of a monitoring network system.

Particular attention has been paid to communication and management aspects.

Due to a restrain on the discharge potential of the Collettori Emissari Occidentali, located in the Milan metropolitan area, the Deviatore Olona cannot yet be used to its full capacity.

This situation needs to be quickly overcome. 
A sound solution seems to increase the area of the cross section of the Canale Olona in order to allow the flow of the predicted project discharge, defined by the Po Basin Authority.

The Deviatore Olona crosses heavily built areas creating very delicate interactions.

North Lambro river together with upgraded section of the Naviglio Pavese, through an underground bypass, reach a discharge potential of approximately $100 \mathrm{~m}^{3} / \mathrm{s}$ at the distal section of Canale Deviatore. During events of small return period it is possible to deviate into the CSNO a discharge of about $70 \mathrm{~m}^{3} / \mathrm{s}$, as predicted by the Agreement Program for the hydraulic safeguard of Milan.

To avoid accidents that might trigger further critical or dangerous situations, a remote control system, positioned on Vighignolo node, able to predict flows in the Canale Deviatore, is strongly recommended. Such real time predictiontool should be able to elaborate pluviometric and meteorological data, currently recorded only by the Civil Protection Service, and hydrometric heights on the Deviatore, through the implementation of the sensor network already present along the Canale Deviatore.

\section{References}

[1] Brown M. "Situazione attuale e interventi prioritari per la salvaguardia del territorio del Comune di Milano" La difesa idraulica dei territori fortemente antropizzati a cura di U. Maione e A. Brath, 1997

[2] Elefanti A. "Sicurezza idraulica della città di Milano" La difesa idraulica dei territori fortemente antropizzati a cura di U. Maione e A. Brath, 1997

[3] Borrini E. "Ruolo del CSNO nella difesa idraulica del territorio milanese" La difesa idraulica dei territori fortemente antropizzati a cura di U. Maione e A. Brath, 1997 